Marina Anna Colasacco*

\title{
A cognitive approach to teaching deictic motion verbs to German and Italian students of Spanish
}

https://doi.org/10.1515/iral-2018-2007

\begin{abstract}
In this study we compare two instruction approaches (cognitive and traditional) to the teaching of Spanish deictic motion verbs -ir, venir, llevar and traer- to German and Italian learners. We also analyse whether the students' first language (Italian or German) influences the results of the cognitive methodology we applied. The Cognitive Instruction combined the basic principles of Cognitive Grammar with those of Processing Instruction for activities in which students practice both comprehension and production. We carried out a survey of 274 university students who were learning Spanish (Level B1) at universities in Italy and Germany. Students carried out a test prior to receiving the instruction and three tests subsequently, one immediately afterwards, the second a week later and the third, a month later. The cognitive methodology proved to be beneficial and positive. The students who received cognitive instruction made better form-meaning connections and showed higher performances in the use of deictic motion verbs than those who received traditional instruction. The learners' L1 did not appear to influence the results of the groups that received the cognitive method of instruction.
\end{abstract}

Keywords: cognitive grammar, processing instruction, deictic motion verbs, second language learning, Spanish as a foreign language, cognitive linguistics, language pedagogy

\section{Introduction}

Motion is an essential conceptual domain in both physical development and human cognition, and due to the frequency to which we refer to it in everyday communication, its expression is a basic factor of all languages. Every language invites speakers to adopt a particular perspective in the events they

*Corresponding author: Marina Anna Colasacco, Centro Linguistico di Ateneo, Università degli Studi G. D’Annunzio di Pescara, Viale Pindaro, 42 - 65127 Pescara, Italy,

E-mail: marinacolasacco@tin.it 
describe. When we speak, our experiences of the world are filtered through our choice of words, and not only through the individual standpoint we take, but also through the wide set of options offered by the particular language we are speaking. "This is the core of what has become known as the thinking-for-speaking hypothesis (Slobin 1996), which states that the language that we speak may operate online to influence how we articulate experiences" (Cadierno and Hijazo-Gascón 2013: 99). This unconscious training takes place from our earliest childhood and creates patterns that are resistant to the changes required for the acquisition of second or foreign languages (L2/FL). In this way, learning a L2/FL involves learning to express concepts in the particular, characteristic way of the new language, with the necessary reorganization of thought patterns this entails.

In this study we analyse if this issue can be overcome with the aid of a certain type of instruction and whether the differences in the L1s of our participants influence the results of this kind of instruction.

\section{Motivation}

Motion verbs ir, venir, llevar and traer (to come, to take and to bring in English) have a directional component that enables them to be used in relation to the location of the participants to the conversation -typically the position of the speaker-, adding contextual information to the discourse. Due to this specific characteristic, which makes them different from other motion verbs, they are called deictic verbs of motion (henceforth DMV).

Error analysis has shown that learners of Spanish as L2/FL (Vázquez 1991; Fernández 1997; Lenarduzzi 1999; Bordonaba-Zabalza 1998; Sánchez-Iglesias 2003; Gutiérrez-Quintana 2005; De Benedetto 2006; Rakaseder and Schmidhofer 2014; Lewandowski 2014; Hijazo-Gascón 2017) have considerable difficulty with the use of DMV, making persistent errors, in the sense that students continue to make the same mistakes even as they progress to higher levels of Spanish (Fernández 1995: 149). According to the author, DMV are pairs of opposites in the target language that are expressed in a similar way in the first language (L1), but differing in some nuance of meaning not always perceived by learners.

This problem affects learners who are native speakers (NS) of languages such as German, Catalan, French, English, and Italian among others, whose DMVs are governed by a set of rules different from Spanish (Gathercole 1977, 1978). In Spanish, for example, the use of venir (to come) implies only and always 
movement towards the speaker (deictic centre of the speech act). This is not the case of other languages -such as Italian- that allow the projection of the origo ${ }^{1}$ towards the listener, enabling venir to describe movement towards both the speaker and the listener. Also not of German, which, in addition to the projection of the origo, highlights the relevance of the Aktionsart factor (Ricca 1993). According to this factor, "coming" (ventive) verbs describe the terminal phase of the movement, and "going" (itive) verbs describe the initial or development phase of the process. ${ }^{2}$

Because learners are unaware of the deictic function of the DMV in Spanish, they do not understand their meaning, and in reconstructing the L2/FL system, they apply the rules of their L1. In other words, they activate and transfer their motion pattern to the target language, compromising the correctness of the speech. When the mistake does not impede or invalidate communication, it may not be noticed by the speaker, which will cause the problem to become fossilized.

Since Fillmore's research (1966 onwards) about the appropriateness conditions for DMV in English, countless studies have been conducted to analyse the use of those verbs in several languages, which confirms the relevance of this issue. Many of this studies have focused on one single language, e. g. Cifuentes Honrubia (2007), Sudo (2015), Tapia Yepes (2011). Many other works have been based on cross-linguistic analysis, e. g. Gathercole (1977, 1978), Ibáñez (1983), García Padrón (1985), Ricca (1991, 1993), Marongiu (1997), Di Meola (2003), Oshima (2006), Arroyo (2011), Nakazawa (2006, 2007, 2009), Lewandowski (2007, 2008, 2014), Verde (2014), Colasacco (2014), Chui (2015, 2016), Suadoni (2016), Hijazo-Gascón (2017).

\section{Background}

With very few exceptions, DMV have been largely ignored in SFL (Spanish as a Foreign Language) syllabuses and textbooks, and in the classroom (Chui 2015: 54). Although for many students of different L1s they are difficult to learn, in SFL textbooks these verbs are normally included in broader contexts -notional-

1 The notion of the deictic centre or origo was first proposed by Bühler (1934). The origo is the central point in space and time or Nullpunkt from which the deixis is oriented, formed by the trilogy: I-here-now (in Latin ego-hic-nunc).

2 The itive and ventive verbs are the translation of the English terms "coming" and "going" verbs, proposed in the Romance tradition by Ricca (1991). Itive verbs include ir and llevar and ventive verbs, venir and traer. 
functional, lexical and cultural-, and are present in exercises relating to their morphology or to the study of verbal periphrases. Some textbooks do include the briefest reference to their use, stating the importance of the direction of the movement, but it is confined to a rule in the margin, where it remains unattended to within the broad flow of communicative contexts (for a more detailed review, see Colasacco, $\mathrm{PhD}$ thesis [in process]).

Although research into grammatical instruction has been very productive in recent years, grammar is still taught in a traditional, unintegrated way in most classrooms that focus on the accuracy of form, and on learning rules via mechanical exercises (Larsen-Freeman 2015: 263-264). Indeed, as Achard (2008: 441) points out, grammar rules are presented as a property of the linguistic system being learned and not as a result of the speaker's choice. On this question, VanPatten and Cadierno (1993: 238) already stated over two decades ago that the traditional forms of presenting and practising grammar do not improve the manner in which the students process the input, and therefore do not provide intake for the development of the linguistic system.

We believe that the best way to deal with complex linguistic issues in the SFL classroom is to attract the conscious, reflective attention of the students, offering them a type of instruction to help them to focus on these complex forms and connect them with their meanings. "This is particularly important for structures that are vulnerable to fossilization, such as ones that are subject to cross-linguistic influence" (Larsen-Freeman 2015: 266).

In fact, encouraging students to make form-meaning connections on the basis of practice exercises may be enough for learning certain aspects of grammar, but there are other more complex linguistic forms that cannot be grasped by the student independently; in this case, they must be given explicit information about the target structure being studied (DeKeyser and Prieto-Botana 2013: 453).

Instruction can also play a facilitating role: it can enhance the selective attention of the students towards the form and to form-meaning connections on the basis of the input they receive. It can also speed up the rate of acquisition and help develop greater linguistic competence (Benati and Nuzzo 2017: 3).

Numerous research papers have demonstrated the importance of explicit information or explicit instruction as an effective method of attracting the student's attention to the problem at hand and increasing their learning possibilities (DeKeyser and Prieto Botana 2013; Ellis 2015). Llopis-García (2016: 34) contends that explicit attention in the teaching of grammar helps students process the L2 system and that the development of explicit knowledge is an 
important part of the process, because it may lead to the construction of implicit knowledge. The latter forms the basis of communication in real time.

After reviewing earlier studies, Ellis (2015) claimed that form-centred instruction of L2 has substantial benefits, that explicit instruction is more effective than implicit, and that L2 instruction has long-lasting effectiveness. He also claimed that L2 learning through implicit methods has only limited success, because "although L2 learners are surrounded by language, not all of it 'goes in”' (Ellis 2015: 16).

In relation to the research presented here, which investigates the effectiveness of a cognitive-based teaching alternative for the SFL classroom, a pilot study was designed to implement an explicit grammar instruction for teaching DMV to Italian learners of Spanish (Colasacco 2014). The teaching method combines the principles of Cognitive Grammar (CG) (Langacker 1987 and subsequent publications) and Processing Instruction (PI) (VanPatten 1996, 2002 and subsequent publications) for the design of structured input and output activities.

The combination of CG and PI, initially suggested by Cadierno (2004, 2008), was implemented by Llopis-García (2009) in the teaching of mood selection to German learners of Spanish. As an additional benefit to PI, she proposed a cognitive grammar instruction aimed at reinforcing comprehension of the target form, thus providing enhanced, higher-quality explicit information; She also applied PI to the structuring of input and output. Palacio 2013 also combined this methodology when teaching the difference between the imperfect and the past simple to Maltese learners of Spanish.

In view of the positive results obtained by these researchers, we decided to conduct an experimental study to compare the effects of two methodological approaches for teaching the usage of DMV to Italian and German learners of Spanish: a traditional method of instruction (based on current L2 textbooks) and the cognitive grammar-based instruction implemented in Colasacco (2014). Likewise, given that the target linguistic form is quite complex for both Italian and German students, we also decided to analyse whether the learners' first language influences the results of the cognitive methodology applied. Since Italian belongs to the group of Romance languages and German to that of Germanic languages, these two languages have different levels of affinity with Spanish (a Romance language).

\subsection{Cognitive grammar}

Cognitive Grammar (CG) (Langacker 1987) is a descriptive model of languages included the broader framework of Cognitive Linguistics (Evans and Green 2006; 
Ibarretxe-Antuñano and Valenzuela 2012), which conceives language as an integral part of human cognition and claims that its essence lies in the construction of meaning. Langacker defines it as a usage-based theory, which considers linguistic conceptualizations as just another product of general human faculties. Its central principle is that form and meaning are symbolic and thus inseparable.

As a basis for language teaching, the potential of CG is focuses on three essential elements: "the centrality of meaning, the meaningfulness of grammar, and its usage-based nature” (Langacker 2008: 66). From a pedagogical point of view, "the presupposition that the elements of grammar are bearers of meaning [...] and not mere formal structures that are arbitrarily imposed" (Castañeda and Alhmoud 2014: 59) is essential.

On this question, Castañeda (2004: 1-3) argues that CG reveals the "figurative" condition of language, and that this gives rise to advantageous circumstances when it comes to pedagogically adapting descriptions of grammar in the FL classroom. For example, viewing language as a tool for the construction of alternative representations of the same objective situation allows us to identify the basic value of grammatical and lexical resources. It also enables us to describe and explain discoursive uses linked to context and to the different perspectives of representation of real scenes.

Through an effective instruction that highlights that different linguistic forms express the same reality in a different way, students can notice the differences between the grammar systems of their native and target languages, and become aware of the linguistic particularities of the latter.

Along similar lines, Llopis-García (2016: 36) argues that

In the world of foreign language teaching and SFL in particular, the 'ticking' must be to focus on the conceptualization differences between the students' L1 and Spanish. CG offers some conceptual tools that may create 'opportunities for languaging', that is, the ability to create the meaningful communication of our experience through language use.

On this same question, “the 'imaginistic' character of linguistic representation" (Castañeda 2004: 2) allows us to establish parallels with the general principles of perception and with other forms of representation, such as graphics, intuitively accessible to speakers of other languages. In fact, "image comes before speech and is therefore more universal, more compatible, and more intelligible" (Llopis-García et al. 2012: 66).

From a pedagogical point of view, meaning-based language study gives students the chance to control the forms and to decide when and how to use them, depending on the meaning they wish to convey. 


\subsection{Processing instruction}

Processing Instruction (PI) -a teaching method that applies the principles of the Input Processing Model (IP) to the L2/FL classroom (VanPatten 2002, 2004)- could be classified within the type of grammatical instruction known as Focus on Form (Long and Robinson 1998; Doughty and Williams 1998). According to Long (1991), Focus on Form is a pedagogical intervention based on "overtly draw(ing) students' attention to linguistic elements as they arise incidentally in lessons whose overriding focus is on meaning, or communication" (p. 56).

PI and IP are involved in the transformation of input into intake through comprehension (VanPatten 1996). While the Model analyses the psycholinguistic mechanisms applied by learners when linking a linguistic form with its meaning (VanPatten 2004), PI takes an explicit reflection about the target form to the classroom, as well as about the processing strategies that prevent the students from making the right form-meaning connections (FMC). The intervention of PI culminates with structured input activities, in which the input is manipulated in such a way that the student will only be able to successfully complete the exercise if the target linguistic form is processed correctly. The ultimate purpose is to prevent erroneous strategies implemented by students and to reinforce the right ones, as well as to ensure that the new linguistic item can be incorporated into the learner's interlanguage.

The first studies with PI (VanPatten and Cadierno 1993) opened a line of research that has given rise to numerous subsequent papers that report on the benefits obtained by students from the application of this teaching method (for a review, see Lee 2015; Benati 2016).

\section{Our research}

This paper has two fundamental objectives. The first one was to compare the effects of two different methods for teaching DMV -ir, venir, llevar and traer- to learners of Spanish with Italian and German L1s. The two methods were (1) a cognitive-based grammatical instruction combined with comprehension and production practice, prepared according to the principles of Processing Instruction (VanPatten 1996, 2002, 2004); and (2) a traditional communicative teaching method based on current textbooks, aimed only at production. Our second objective was to assess whether the learners' first language (Italian and German) hat an effect on the results of the cognitive teaching method. 
With this in mind, we posed the following research questions:

Q1. Will there be significant differences between the experimental groups and the control group according to the type of instruction received?

Q2. Will there be significant differences on the results obtained by the cognitive instruction groups on the basis of their first language (Italian or German)?

\subsection{Target form}

For the purposes of this study, we will analyse the uses of DMV by taking into account only their prototypical meaning, that is, the one that describes a movement related to a point of observation linked to the position of the speaker. The metaphorical meanings of these verbs, as well as their use in verbal periphrasis or locutions, will not be considered.

Following the theoretical frameworks proposed by Fillmore (1975) and Ricca (1993), we developed a comparative analysis of the conditions in which DMV are used in Spanish, Italian and German. The aspects considered were (1) the direction of movement (towards the speaker, towards the listener or towards a third location), (2) the moment at which the movement was performed (moment of speaking or moment of reference before or after the act of speaking), (3) movement made in the company of the interlocutor (comitative contexts); and (4) the home-base case. Fillmore (1975) states that home base refers to the speaker or listener's normal place of residence or other places more or less closely associated with them.

According to Ricca (1993), Spanish and Italian both appear to be completely deictic languages, although the use of DMV differs in each language.

In Spanish venir (and traer) have a very restricted use, only describing movements made towards the speaker. This is so for movements made at the coding time, and for movements made at the reference time (past or future). In the latter, the use of venir will be possible when that speaker has been or intends to be at the target goal of the movement at the time it takes place (e. g. En julio me mudaré a París. ¿Vendrás a visitarme? [I'm moving to Paris in July. Will you come visit me?]). This condition is also required for movements towards the speaker's home base. ${ }^{3}$

3 In these cases, venir and traer are used when the presence of the speaker at the destination of the movement is assumed even though the speaker is not there at the time of speaking; for example: Regresaré a casa por la noche; puedes venir, si quieres). (I will be returning home in the evening; you can come if you want). 
Regarding comitative contexts, in Spanish the use of venir is only possible when the speaker is inviting the listener to accompany him/her, and cannot be used in the answer to this invitation (for example: ¿Vienes conmigo a París? [Would you like to come to Paris with me?]). In all other cases, Spanish uses the verb ir (to go). ${ }^{4}$ (Gathercole 1977, 1978; Ricca 1993; Cifuentes Honrubia 2007; Ibáñez 1983).

In Italian, the use of venire (to come) describes movements towards the speaker and towards the listener (displacement of the origo towards the listener) that take place either at the moment of speaking or at a different time (before or afterwards). As a result, in comitative contexts, venire is used both to invite someone to accompany you, as well as to respond to the invitation. Andare (to go) is only used to describe movements towards a third location other than that of the speaker and the listener (Ricca 1993; Di Meola 2003).

In German (defined by Ricca 1993 as a prevailing deictic language) the use of DMV is influenced not only by the deictic component but also by the Aktionsart factor. In this way, when kommen and gehen ('to come' and 'to go') are conditioned by the deixis, they are used in the same way as in Italian. But there are cases in which kommen and gehen do not indicate relevant targets in a deictic sense, and instead emphasize the different phases of the movement: the final stage of the process is expressed with kommen (to come) and the beginning or development stage, with gehen (to go). In this sense, kommen takes on the meaning of llegar in Spanish and arrivare in Italian. (Ricca 1993; Ibáñez 1983). (e.g. Geh geradeaus, dann links, so kommst du zu einem Fluß. [Go straight on, then turn left, so you'll get to the river]). In this example, kommen codifies the final stage of a movement whose beginning is expressed by gehen (to go).

\subsection{Background information and participants in the study}

274 university students who were learning SFL at level B1 in the Common European Framework Reference participated in this study: 135 were Italian native speakers from the Università degli Studi Gabriele D’Annunzio (UDA) in

\footnotetext{
4 We will only be referring to the verbs ir and venir as they both have equivalents: in Italian (andare and venire) and German (gehen and kommen). The meanings of the Spanish verbs llevar and traer (take and bring) are expressed with a single verb in both Italian (portare) and German (bringen). As far as llevar behaves in the same way as ir and traer as venir, the use conditions for ir are the same as for llevar, and the use conditions for venir are the same as for traer.
} 
Pescara, Italy; and 139 were German native speakers from the Universities of Heidelberg and Kassel (both in Germany).

The initial pool of 341 participants was randomly assigned to one of three research groups. They then completed a questionnaire and a pretest. This initial group was then whittled down to the final group of 274 participants on the basis of the following criteria: (a) participants had to be native speakers of either Italian or German, (b) they could not be bilingual ItalianSpanish or German-Spanish, (c) they did not achieve scores of over $60 \%$ in the pretest.

Three groups -two experimental and one control- were formed for each language. The experimental groups (1) ITA.COG and GER.COG -taught using a cognitive method- and (2) ITA.TRA and GER.TRA -taught with a traditional teaching method-; and the control groups (3) ITA.CON and GER.CON, who were not taught about DMV. In order to analyse the general effects of the experimental teaching methods, the six groups (three groups of Italians and three of Germans) were organized according to the type of instruction they received. To this end, three groups were considered: $C O G$ (Italians + Germans with cognitive instruction), TRA (Italians + Germans with traditional instruction) and CON (Italians + Germans with no instruction). (Cf. Table 1).

Table 1: Research groups.

\begin{tabular}{llllllr}
\hline GROUP & ITALIAN & n. & GERMAN & n. & ITALIAN + GERMAN & n. \\
\hline COGNITIVE & ITA.COG & 57 & GER.COG & 59 & COG & 116 \\
TRADITIONAL & ITA.TRA & 47 & GER.TRA & 44 & TRA & 91 \\
CONTROL & ITA.CON & 31 & GER.CON & 36 & CON & 67 \\
\hline
\end{tabular}

\subsection{Materials}

Two instruction packages (Cognitive and Traditional) and data collection tools were designed and implemented (see Subsection 4.3.2).

\subsubsection{Instruction packages}

For the TRA group we prepared a 50-minute session based on Level A2 SFL textbooks with a communicative, task-based approach; the DMV-related 
activities were adapted to the notional-functional and lexical contents for level B1 of the Syllabus approved by the Instituto Cervantes (Plan Curricular del Instituto Cervantes 2006). The subject of the lesson regarded "Parties and Celebrations". During this lesson students did not receive explicit information about the DMV. They completed four practice exercises on DMV using the grammar explanations provided in the analysed textbooks as support (see sample in Figure 1).

b) Completa los siguientes diálogos telefónicos con las formas correctas de los verbos $\mathrm{ir}$, venir, llevar y traer contenidas en el siguiente recuadro:

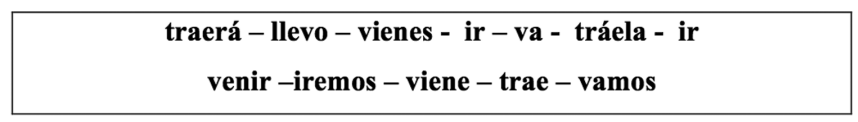

ANA Y LUISA

Ana: Hola, Luisa ;Por fin puedo hablar contigo! Quería invitarte a una fiesta el sábado aqui en mi casa. ¿

Luisa: ¿El sábado? ¡Qué pena! No podré Lo siento mucho. Y es que justo el sábado quisiera dejarla sola en casa.

Ana: iPues Seguro que lo pasa muy bien con nosotros. a la fiesta y así le presentas a tus amigos de la uni...!

Luisa: Bueno, si insistes... Se lo comentaré a Caterina en cuanto llegue, y si no está muy cansada, - ¿Te parece?

Ana: De acuerdo. ¿Crees que esos caramelos italianos rellenos de cremita que me gustan tanto?

Luisa: ¡jajaja! No lo sé.. Te prometo que si los algunos el mismo sábado.

Figure 1: Sample of a traditional instruction activity.

The COG instruction contained a theoretical part (explicit grammatical information about the functioning of the target form, and explicit information about the processing problem) and a practical part comprised of four activities (two interpretation and two production). The principles of PI were applied in the design of both comprehension and production activities (see sample in Figure 2). The theoretical concepts behind CG, especially those of perspective and image-schema path, served as a basis for the explicit information about the target form. All explanations were supported with images and cartoons to provide representational form-meaning connections. We highlighted the situations in which the students' processing strategies led to an incorrect selection of verbs (i. e. transferring meaning and use from their L1) in the construction of the statement. 


\begin{tabular}{|l|l|l}
\hline $\begin{array}{c}\text { A.- ¿A qué lugares se refiere Elena? } \\
\text { A quali luoghi fa riferimento Elena? }\end{array}$ & $\begin{array}{c}\text { AQUí } \\
\text { A donde ella está } \\
\text { Al luogo dove si } \\
\text { trova lei }\end{array}$ & $\begin{array}{c}\text { ALLÍ } \\
\text { A otros lugares } \\
\text { Ad altri luoghi }\end{array}$ \\
\hline 1. ¿Podéis traer mañana los portátiles? Los necesitaremos. & & \\
\hline 2. Si te gusta, puedes llevarte el vestido rojo. Te queda muy bien. & & \\
\hline 3. Ha traído dulces para todos. iQué generoso! & & \\
\hline 4. Espérame, ahora vengo y me lo cuentas. & & \\
\hline 5. ¡Deja de gritar, ya voy! ¡Qué pesado eres! & & \\
\hline 6. He venido para hablar con Sergio. & & \\
\hline 7. Si puedes, lleva a tu novio. Quisiera conocerlo. & \\
\hline 8. ¿Quién, Miguel? No, nunca fue a visitarme. & & \\
\hline
\end{tabular}

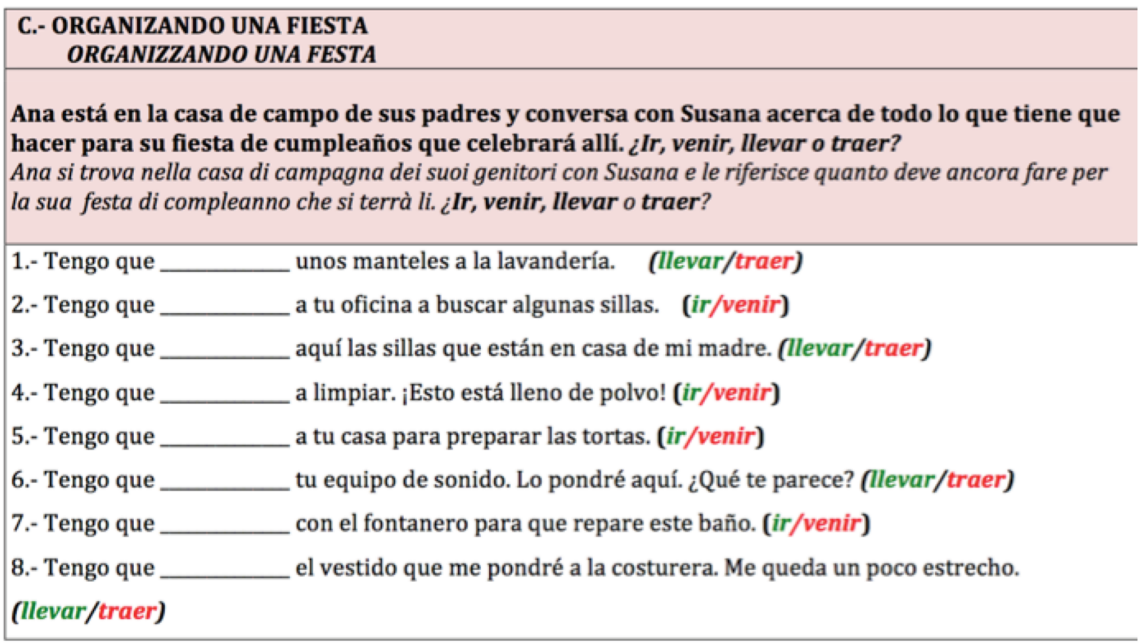

Figure 2: Sample from the cognitive instruction activity.

\subsubsection{Data collection tools}

The data were collected with an initial questionnaire, a pretest (PT) and three post-tests. The first two were conducted before the instruction in order to fit the sample group to the criteria mentioned in Section 4.2.

The post-tests were conducted after the teaching sessions: post-test 1 (T1), immediately afterwards; post-test 2 (T2), one week later and post-test 3 (T3), one month later. Each test contained 32 activities: 16 interpretation and 16 production activities (see sample in Figure 3). 


\begin{tabular}{|c|c|c|c|}
\hline \multicolumn{4}{|c|}{$\begin{array}{l}\text { A.- CAPERUCITA ROJA: Nueva Versión. } \\
\text { ROTKÄPPCHEN: NEUE VERSION. }\end{array}$} \\
\hline \multicolumn{4}{|c|}{$\begin{array}{l}\text { Lee atentamente los enunciados. Según el significado de los verbos empleados -ir, venir, } \\
\text { llevar o traer-, determina si: } \\
\text { A) Caperucita está hablando con la abuelita por el móvil. } \\
\text { B) Caperucita está en casa de la abuelita, hablando con ella. }\end{array}$} \\
\hline \multicolumn{4}{|c|}{$\begin{array}{l}\text { Lesen Sie die folgenden Äußerungen. Entscheiden Sie jeweils nach der Bedeutung der } \\
\text { benutzten Verben -ir, venir, llevar oder traer-, ob: } \\
\text { A) Rotkäppchen mit der Oma mit dem Handy spricht. } \\
\text { B) Rotkäppchen zu Hause bei der Oma ist und mit ihr spricht. }\end{array}$} \\
\hline & & $\begin{array}{l}\text { A (Por el } \\
\text { móvil) }\end{array}$ & $\begin{array}{l}\text { B (Casa de } \\
\text { la abuela) }\end{array}$ \\
\hline 1 & Te he traído el labial que querías. ¡Espero que te guste! & & \\
\hline 2 & Te compré el CD de Justin Biber; te lo llevo. & & \\
\hline 3 & Voy a tu casa para que me enseñes a bailar tango. & & \\
\hline 4 & Mañana vengo a verte más temprano. & & \\
\hline 5 & Traigo todo lo necesario para la fiesta. & & \\
\hline 6 & He decidido llevar a mi novio conmigo para que lo conozcas. & & \\
\hline 7 & El lunes voy a visitarte por la tarde. & & \\
\hline 8 & $\begin{array}{l}\text { Me gusta jugar al tenis contigo. Por eso vengo a tu casa todas las } \\
\text { semanas. }\end{array}$ & & \\
\hline
\end{tabular}

\section{D.- DE VACACIONES EN MADRID URLAUB IN MADRID}

Sergio está de vacaciones en Madrid y le escribe a su amiga Bea, que está en Pescara. Completa los mensajes electrónicos con la forma adecuada de ir, venir, llevar y traer.

Sergio macht Urlaub in Madrid und schreibt Bea, die in Pescara wohnt. Ergänzen Sie die Aussagen mit der geeigneten Form der Verben ir, venir, llevar und traer.

Sergio: ¡Hola! Te cuento que Madrid es maravillosa. Tienes que (ir/venir) a conocerla lo antes posible.

Bea: ¡Me encantaría! Pero ya sabes que por ahora no puedo (ir/venir). Tengo que presentar aún tres

exámenes y estoy estudiando...

Sergio: ¡Qué pena! Ayer estupendo!

Bea: ¡Qué guay! ¿Podrías (fui/vine) al Museo del Prado y vi Las Meninas de Velázquez. ¡Es un cuadro

Sergio: Pues claro. ¿Te (llevarme/traerme) una reproducción? No sé, tal vez un póster.

Bea: A ver...sí. Puedes (Ilevo/traigo) algo más?

Sergio: ¡Jajajaj! Como quieras. En cuanto regrese de mi viaje, (llevarme/ traerme) una foto gigante de Casillas... jajaja

(llevo/traigo) tus encargos. Un beso.

Figure 3: Sample from one of the post-tests.

\subsection{Procedure}

The teaching sessions and the tests took place during normal class days for the participating groups. Four meetings with each group were scheduled over five weeks. On the first day, students completed the initial questionnaire and the PT. 
On the second day, they were given the instruction session (traditional or cognitive) and students then completed the corresponding practice exercises; after correcting these (for which there was no feedback), the students did T1. A week later they completed T2 and four weeks after the teaching session, they were given T3. All groups completed the same tests (pre- and post-tests). The control groups (ITA.CON and GER.CON) only did the tests, and they did not receive any specific instruction on the target form, or any practice exercises.

\subsection{Results: Scoring, analysis and discussion}

One point (1) was given for an incorrect answer and zero (0) for a correct answer, so the score obtained by the students for each test was equivalent to the number of errors made. For the statistical analysis, the scores were submitted to ANOVA tests (alpha level $=0.05$ ). Later, in order to explore any significant interactions between variables, a Sheffé and Games-Howell post-hoc tests for multiple comparisons were conducted, according to the homogeneity of the variances of the samples evaluated with the Levene Test. A confidence interval of $95 \%$ was used.

\subsubsection{Question 1: Type of instruction}

For this question, the results obtained by the COG, TRA and CON groups in the various different tests (PT, T1, T2, T3) were compared. Table 2 shows the descriptive statistical values calculated on the number of errors made. The scores were submitted to a Two-way repeated measures ANOVA test (alpha level =0.05). Instruction (COG, TRA and CON) served as the between-subjects independent variable (IV), and time (PT, T1, T2 and T3) served as the intrasubject independent variable. The dependent variable (DV) was learning (measured by the number of errors).

The results showed significant differences for the instruction variable: $\left(\mathrm{F}_{[2,271]}=\right.$ 233.324; $\left.p<0.001 ; \eta_{p}^{2}=0.633\right)$, for the time variable $\left(\mathrm{F}_{[2.83,767.84]}=411.865\right.$; $\left.p<0.001 ; \eta_{p}^{2}=0.603\right)$ and in the instruction $x$ time interaction $\left(\mathrm{F}_{[5.67,767.84]}=\right.$ 109.612, $\left.p<0.001 ; \eta_{p}^{2}=0.447\right)$. This interaction can be seen in Figure 4 .

A One-factor ANOVA test for independent groups was conducted separately for each one of the tests. In all cases the IV between the groups was the instruction received (with three levels: COG, TRA and CON), and the dependent variable (DV) was learning (measured by the number of errors).

The results of the ANOVA test on the scores for the pretest revealed significant statistical differences between the three groups $\left(F_{[2,271]}=3.72\right.$; 
Table 2: Descriptive statistics.

\begin{tabular}{llrrrr}
\hline GROUP & TEST & N & M & SD & SE \\
\hline \multirow{4}{*}{ COG } & PT & 116 & 18.03 & 3.28 & 0.30 \\
& T1 & 116 & 2.98 & 3.14 & 0.29 \\
& T2 & 116 & 3.41 & 3.02 & 0.28 \\
& T3 & 116 & 4.47 & 4.05 & 0.38 \\
TRA & PT & 91 & 17.65 & 2.58 & 0.27 \\
& T1 & 91 & 11.66 & 4.38 & 0.46 \\
& T2 & 91 & 11.09 & 5.55 & 0.58 \\
& T3 & 91 & 10.81 & 4.77 & 0.50 \\
CON & PT & 67 & 16.81 & 2.68 & 0.33 \\
& T1 & 67 & 15.28 & 2.45 & 0.30 \\
& T2 & 67 & 15.10 & 2.98 & 0.36 \\
& T3 & 67 & 15.19 & 4.15 & 0.51 \\
\hline
\end{tabular}

\section{Instruction-Time Interaction}

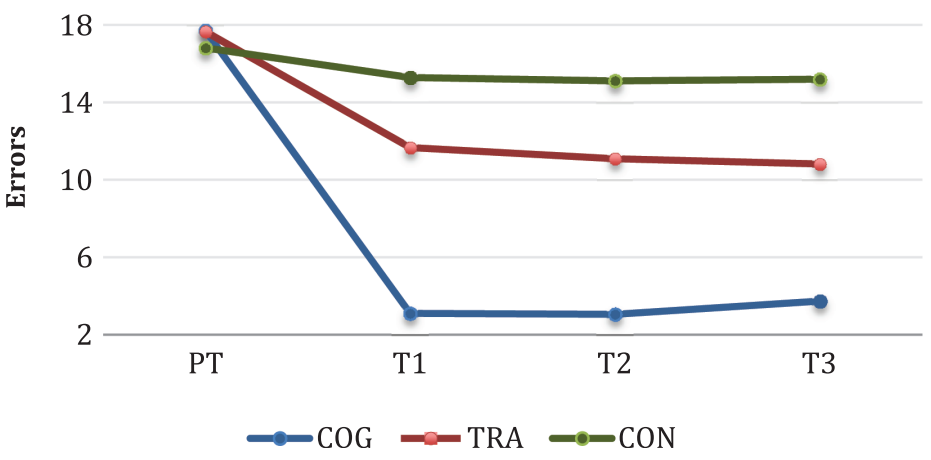

Figure 4: Instruction-time interaction Q1.

$\left.p=0.025 ; \eta_{p}^{2}=0.027\right)$. The Games-Howell post-hoc multiple comparisons test showed a significant difference between the COG and CON groups (Mean Difference $I-J=1.22 ; p=0.019$ ), which shows that the control group had a mean number of mistakes significantly lower than the cognitive group. No significant difference could be seen between the means for CON and TRA, or between the COG and TRA experimental groups. This allowed us to infer that any verified improvement in the performance of the groups that received instruction would be due to said instruction, as the control group (CON) performed slightly better than the others on the pretest ( -1.22 errors).

With regards to the scores in the tests after the instruction (T1, T2 and T3) the One factor ANOVA showed significant differences between groups: for T1 
$\left(\mathrm{F}_{[2,271]}=311.08 ; p<0.001 ; \eta_{p}^{2}=0.697\right)$, for $\mathrm{T} 2\left(\mathrm{~F}_{[2,271]}=200.30 ; p<0.001\right.$; $\left.\eta_{p}^{2}=0.596\right)$ and for T3 $\left(\mathrm{F}_{[2,271]}=139.96, p<0.001 ; \eta_{p}^{2}=0.508\right)$ (cf. Table 3).

Table 3: Results of the analysis of variance for PT, T1, T2 and T3.

\begin{tabular}{lrlrrrr}
\hline Source & $\begin{array}{r}\text { Sum of squares } \\
\text { (Type III) }\end{array}$ & gl & Quadratic mean & F & Sign. & Partial Eta Squared \\
\hline Groups/PT & 63.491 & 2 & 31.746 & 3.721 & 0.025 & 0.027 \\
Groups/T1 & 7484.512 & 2 & 3742.256 & 311.088 & 0.000 & 0.697 \\
Groups/T2 & 6515.354 & 2 & 3257.677 & 200.301 & 0.000 & 0.596 \\
Groups/T3 & 5244.194 & 2 & 2622.097 & 139.958 & 0.000 & 0.508 \\
\hline
\end{tabular}

Consequently, Scheffé and Games Howell post-hoc tests with a confidence interval of $95 \%$ were conducted. The significant results are set out in Table 4.

Table 4: Summary of the comparisons between the groups for PT, T1, T2 and T3.

\begin{tabular}{|c|c|c|c|}
\hline (I) Group & Contrast & Mean Difference (I-J) & Significance $(p<0.05)$ \\
\hline \multirow[t]{2}{*}{ PT } & $\mathrm{CON}>\mathrm{COG}$ & -1.22 & 0.019 \\
\hline & $\mathrm{COG}>\mathrm{CON}$ & $-12.30^{\star}$ & 0.000 \\
\hline \multirow[t]{3}{*}{ T1 } & COG $>$ TRA & $-8.68^{\star}$ & 0.000 \\
\hline & $\mathrm{TRA}>\mathrm{CON}$ & $-3.62^{\star}$ & 0.000 \\
\hline & $\mathrm{COG}>\mathrm{CON}$ & $-11.70^{\star}$ & 0.000 \\
\hline \multirow[t]{3}{*}{ T2 } & COG $>$ TRA & $-7.68^{\star}$ & 0.000 \\
\hline & $\mathrm{TRA}>\mathrm{CON}$ & $-4.02^{\star}$ & 0.000 \\
\hline & $\mathrm{COG}>\mathrm{CON}$ & $-10.73^{\star}$ & 0.000 \\
\hline \multirow[t]{2}{*}{ T3 } & COG $>$ TRA & $-6.35^{*}$ & 0.000 \\
\hline & TRA $>\mathrm{CON}$ & $-4.38^{\star}$ & 0.000 \\
\hline
\end{tabular}

In order to assess the effect of the instruction over time, a One factor ANOVA with repeated measures was performed for each group separately. In all cases, the intra-group independent variable was time (with four levels: PT, T1, T2 and T3), and the DV was learning (measured in terms of the number of errors made). The results are set out in Table 5 .

Finally, Bonferroni pairwise comparisons tests were conducted to identify the significant intra-group differences along all the tests. All significant results are set out in Table 6. 
Table 5: Results of the analysis of variance for COG, TRA, and CON.

\begin{tabular}{lrcrrr}
\hline Source & $\begin{array}{r}\text { Sum of squares } \\
\text { (Type III) }\end{array}$ & gl & Quadratic mean & F & $\begin{array}{r}\text { Significance } \\
(\mathbf{p}<\mathbf{0 . 0 5})\end{array}$ \\
\hline Time/COG & 18206.914 & 2.522 & 7220.268 & 848.691 & 0.000 \\
Time/TRA & 2883.451 & 2631 & 1096.022 & 79.518 & 0.000 \\
Time/CON & 131.642 & 2.602 & 50.596 & 5.783 & 0.002 \\
\hline
\end{tabular}

Table 6: Summary of the intra-group comparisons for PT, T1, T2 and T3.

\begin{tabular}{llrr}
\hline (I) Group & Contrast & Mean Difference $(\mathbf{I}-\mathbf{J})$ & Significance $(\mathbf{p}<\mathbf{0 . 0 5})$ \\
\hline COG & T1 $>$ PT & $-15.04^{*}$ & 0.000 \\
& T1 $>$ T3 & $-1.48^{*}$ & 0.011 \\
& T2 $>$ PT & $-14.62^{*}$ & 0.000 \\
& T3 $>$ PT & $-13.56^{*}$ & 0.000 \\
TRA & T1 $>$ PT & $-5.99^{*}$ & 0.000 \\
& T2 $>$ PT & $-6.56^{*}$ & 0.000 \\
& T3 $>$ PT & $-6.84^{*}$ & 0.000 \\
& PT $>$ T1 & $-1.52^{*}$ & 0.000 \\
CON & PT $>$ T2 & $-1.70^{*}$ & 0.000 \\
& PT $>$ T3 & $-1.61^{*}$ & 0.000 \\
\hline
\end{tabular}

\subsubsection{Discussion of results}

The results of the statistical tests revealed that the COG group performed significantly better than the TRA and CON groups in all the tests conducted subsequent to instruction. If we look at Table 4, which summarizes the comparisons between groups during each test, we can conclude that even though the control group (CON) achieved a slightly higher score than the COG group in the pretest, this result did not improve during post-tests. The TRA group made gains in all subsequent tests compared to the CON group, but never surpassed the COG group. In short, the improvements made by the COG group were clearly greater than those achieved by the TRA or CON groups.

In order to understand these results better, it is important to bear in mind that the students taking part in the survey were already familiar with the target form, in that DMV are first studied at beginner levels of SFL learning; these verbs are also frequently used in real everyday communication. However, the mistakes made by the students in the pretest revealed the same difficulties identified in the error 
analyses we reviewed, where students were unaware of (1) the deictic component that confers meaning to the DMV and (2) of the processing problem: applying strategies that cause the improper use of these verbs due to the L1 interference.

As to the effects over time (cf. Table 6), the tests conducted after a week and after a month (T2 and T3) showed that both the TRAD group and the COG group maintained the gains obtained in T1. The TRAD group showed no significant variations with respect to T1. The COG group showed a slight difference in $\mathrm{T} 3$ compared to T1, which however did not overshadow the clear benefits obtained over the TRAD group. After the cognitive teaching session, the COG students made better form-meaning connections and performed more effectively than the students who received traditional instruction.

\subsubsection{Question 2: The influence of the first language}

In order to assess whether the students' first language (German or Italian) had any influence on the benefits of the cognitive instruction, we compared the results obtained for the ITA.COG and GER.COG in each of the tests. Table 7 shows the descriptive statistical values calculated on the basis of the number of errors made. The scores were submitted to a Two-way repeated measures ANOVA test (level alpha =0.05). First language (ITA.COG and GER.COG) served as the between-subjects independent variable (IV), and time (PT, T1, T2 and T3) was the intra-subject independent variable. The dependent variable (DV) was learning (measured by the number of errors). The results showed significant differences for the time variable: $\left(\mathrm{F}_{[2.53,287.90]}=855.670 ; p<0.001 ; \eta_{p}^{2}=0.882\right)$ no significant differences for the $L 1$ variable: $\left(\mathrm{F}_{[1]}=1.928 ; p=0.168 ; \eta_{p}^{2}=0.017\right)$ and for the interaction first language $x$ time $\left(\mathrm{F}_{[2.53,287.90]}=1.995, p=0.125 ; \eta_{p}^{2}=0.017\right)$. This interaction can be seen in Figure 5.

Table 7: Descriptive statistics.

\begin{tabular}{llrrrr}
\hline GROUP & TEST & N & M & SD & SE \\
\hline \multirow{4}{*}{ ITA.COG } & PT & 57 & 17.70 & 2.96 & 0.40 \\
& T1 & 57 & 3.11 & 2.43 & 0.32 \\
& T2 & 57 & 3.05 & 2.53 & 0.33 \\
& T3 & 57 & 3.74 & 2.68 & 0.35 \\
ALE.COG & PT & 59 & 18.34 & 3.56 & 0.47 \\
& T1 & 59 & 2.86 & 3.72 & 0.48 \\
& T2 & 59 & 3.75 & 3.42 & 0.45 \\
& T3 & 59 & 5.17 & 4.96 & 0.64 \\
\hline
\end{tabular}




\section{L1-Time Interaction}

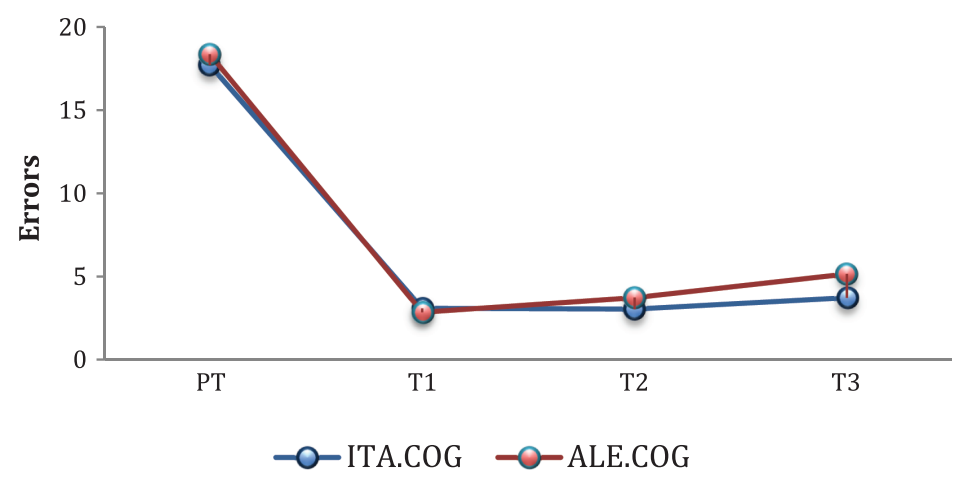

Figure 5: Cognitive instruction-L1 interaction Q2.

A One-factor ANOVA test for independent groups was performed separately for each test. In all cases, the IV between the groups was first language (with two levels: ITA.COG and GER.COG), and the DV was learning (measured in terms of the number of errors). The confidence interval was $95 \%$. The results did not reveal any significant differences between ITA.COG and GER.COG in any of the tests, corroborating the aforementioned mixed Anova test results.

To identify significant intra-group differences, Bonferroni pairwise comparisons tests were performed, with a confidence interval of $95 \%$. The significant results are set out in Table 8.

Table 8: Summary of the intra-group pairwise comparisons for PT, T1, T2 and T3.

\begin{tabular}{cccr}
\hline (I) Group & Contrast & Mean Difference $(\mathrm{I}-\mathrm{J})$ & Significance $(\mathbf{p}<\mathbf{0 . 0 5})$ \\
\hline ITA.COG & T1 $>$ PT & $-14.60^{*}$ & 0.000 \\
& T2 $>$ PT & $-14.65^{*}$ & 0.000 \\
ALE.COG & T3 $>$ PT & $-14.00^{*}$ & 0.000 \\
& T1 $>$ PT & $-15.48^{*}$ & 0.000 \\
& T1 $>$ T3 & $-2.31^{*}$ & 0.002 \\
& T2 $>$ PT & $-14.59^{*}$ & 0.000 \\
& T3 $>$ PT & $-13.56^{*}$ & 0.000 \\
\hline
\end{tabular}

\subsubsection{Discussion of results}

The statistical tests revealed no significant differences between the groups that received Cognitive Instruction. In other words, there were no differences 
between the mean scores for the pretest for ITA.COG and GER.COG, nor for any of the tests conducted after receiving Cognitive Instruction. In T2 and T3, both the German and Italian native speakers maintained the same benefits obtained in $\mathrm{T} 1$.

In the case of the GER.COG group, the intra-group results showed a significant difference between T3 and T1: the mean number of mistakes made in T3 (one month after the instruction) was significantly higher than the mean number of mistakes for T1 (immediately afterwards) (cf. Table 8). In spite of this, the T3 scores for the GER.COG group were still substantially higher than in the PT and in the comparison between the groups there were no significant differences between the T3 scores for GER.COG and ITA.COG.

The results therefore suggest that the learner's first language had no influence on the effects of the cognitive instruction given to the students. This corroborates that a cognitive methodological approach allows learners to notice and process the differences between the grammatical systems of either L1 and Spanish. Moreover, it enables the students to detect the linguistic particularities of Spanish and how they express the same reality with different linguistic forms.

\section{Conclusions}

Our results suggest the need to reconcile explicit grammar instruction with the communicative classroom by means of an approach that goes beyond the traditional conception of the study of grammar, associated with taxonomies and long lists of rules and exceptions.

Compared to using more textbook-based methods, those students who received the cognitive instruction showed a clearly superior performance in the use of DMV, maintaining these advantages in all subsequent tests, which corroborates the findings of other authors (Llopis-García 2009; Palacio 2013; Colasacco 2014). Students also managed to interpret and produce the DMV according to the schema of Spanish, overcoming the influence of the L1. The cognitive comparison between languages allowed the learners to transfer concepts from their L1 to the L2 and to grasp the differences. The different degrees of affinity between Italian and German with respect to Spanish, however, did not influence the positive results obtained by both Italian and German students that received the cognitive instruction, thus validating its effectiveness on a more general scale.

For many learners of Spanish, DMV are a complex, somewhat obscure structure in terms of the meaning they convey. In these cases, as revealed by 
Farley (2004) and Benati (2004), explicit information is necessary and can positively affect the rate of language acquisition.

The work presented should be added to previous investigation that has combined cognitive grammar and processing instruction in the teaching of SFL. To the best of our knowledge, this is the first study that compares the effects of a cognitive-based methodology with a more traditional communicative production-oriented instruction for the learning of DMV with Italian and German students of SFL. It is also the first to observe the effects of cognitive grammar instruction in the SFL learning of L1s with different levels of affinity with Spanish.

Although we understand that in order to generalise the positive results obtained, it will be necessary to continue our research, we should emphasise that these results should be added to previous findings that confirm the benefits of combining the Cognitive Grammar approach with that of Processing Instruction. This combination creates a methodology that can improve the form-meaning connections made by learners and provides them with the tools they need to make decisions and create language that expresses their true communicative intent.

\section{References}

Achard, Michel. 2008. Teaching construal: Cognitive pedagogical grammar. In Peter Robinson \& Nick Ellis (eds.), Handbook of cognitive linguistics and second language acquisition, 432-455. London: Routledge.

Arroyo, Ignacio. 2011. Verbos itivos y ventivos en español e italiano. Usos concretos y abstractos. In Carsten Sinner, Elia Hernández Socas \& Christian Bahr (eds.), Tiempo, espacio y relaciones espacio-temporales, 15-33. Frankfurt am Main: Peter Lang GMBH.

Benati, Alessandro. 2004. The effects of structured input activities and explicit information on the acquisition of the Italian future tense. In Bill VanPatten (ed.), Processing instruction: Theory, research, and commentary, 207-226. Nueva Jersey: Lawrence Erlbaum.

Benati, Alessandro. 2016. Input manipulation, enhancement and processing: Theoretical views and empirical research. Studies in Second Language Learning and Teaching 6(1). 65-88.

Benati, Alessandro \& Elena Nuzzo (eds). 2017. Instructed Second Language Acquisition 1(1). 1-6. https://journals.equinoxpub.com/index.php/isla (accessed 14 March 2017).

Bordonaba-Zabalza, María. 1998. Aproximación a la interlengua del español en italohablantes. RILCE 14(2). http://hdl.handle.net/10171/4355 (accessed 11 November 2013).

Bühler, Karl. 1934. Sprachtheorie. Die Darstellungsfunktion der Sprache. Jena: Verlag von Gustav Fischer.

Cadierno, Teresa. 2004. Expressing motion events in a second language. In Michael Achard \& Susanne Niemeier (eds.), Cognitive linguistics, second language acquisition and Foreign language teaching, 13-49. Berlín: Mouton de Gruyter. 
Cadierno, Teresa. 2008. Motion events in Danish and Spanish: A focus on form pedagogical approach. In Sabine De Knop \& Teun De Rycker (eds.), Cognitive approaches to pedagogical grammar, 259-294. Berlín and New York: Mouton de Gruyter.

Cadierno, Teresa \& Alberto Hijazo-Gascón. 2013. Cognitive linguistic approaches to second language Spanish: A focus on thinking-for-speaking. In Kimberly Geeslin (ed.), The handbook of Spanish second language acquisition, 96-110. Hoboken, NJ: Wiley.

Castañeda, Alejandro. 2004. Potencial pedagógico de la gramática cognitiva. Pautas para la elaboración de una gramática pedagógica del español/LE. Revista de Didáctica ELE 0. http://www.educacion.gob.es/redele/revistaRedEle/2004/primera.html. (accessed 3 September 2013].

Castañeda, Alejandro \& Zeina Alhmoud. 2014. Gramática Cognitiva en descripciones gramaticales para niveles avanzados de ELE. In Alejandro Castañeda (ed.), Enseñanza de gramática avanzada de ELE. Criterios y recursos, 39-85. Madrid: SGEL.

Chui, Daniel. 2015. Claro que vengo* a tu fiesta: La enseñanza de los verbos deícticos ir/venir y llevar/traer a estudiantes angloparlantes. Revista de Filología y Lingüística de la Universidad de Costa Rica 41(1). 53-77.

Chui, Daniel. 2016. Heritage, second-language and native speakers' intuitions on deictic verbs in spanish: Beyond the linguist's intuitions. Journal of New Approaches in Educational Research 5(2). 81-90.

Cifuentes Honrubia, José Luis. 2007. Verbos deícticos en español. In Alexandra Cunija, Coman Lupu \& Liliane Tasmowski (eds.), Studii de Lingvistica i Filologie Romanica: Hommages offerts a Sanda Reinheimer Rípeanu, 99-112. Bucarest: Editura Universijátii din Bucure.

Colasacco, Marina Anna. 2014. Adquisición de los verbos deícticos de movimiento ir, venir, llevar y traer por aprendientes italianos de E/LE: una propuesta didáctica basada en la gramática cognitiva y la instrucción de procesamiento. Madrid: Nebrija University MA thesis.

De Benedetto, Alfonsina. 2006. Pruebas de producción escrita de HNN italianos. Actas del XVI Congreso Internacional de Asele: La competencia pragmática y la enseñanza del español como lengua extranjera. Oviedo: Ediciones Universidad de Oviedo, 177-183.

DeKeyser, Robert \& Goretti Prieto Botana. 2013. Acquisition of grammar by instructed learners. In Kimberly Geeslin (ed.), The handbook of Spanish second language acquisition, 449-465. Oxford: Blackwell.

Di Meola, Claudio. 2003. I verbi deittici di moto in italiano e tedesco. In Livio Gaeta \& Silvia Luraghi (eds.), Introduzione alla linguistica cognitiva, 181-196. Roma: Carocci.

Doughty, Catherine \& Jessica Williams. 1998. Pedagogical choices in focus on form. In Catherine Doughty \& Jessica Williams (eds.), Focus on form in classroom second language acquisition, 197-261. Cambridge: Cambridge University Press.

Ellis, Nick. 2015. Implicit and explicit language learning: Their dynamic interface and complexity. In Patrick Rebuschat (ed.), Implicit and explicit learning of languages, 3-23. Amsterdam: John Benjamins.

Evans, Vyvyan \& Melanie Green. 2006. Cognitive linguistics: An introduction. Mahwah, NJ and Edinburgh: Lawrence Erlbaum Associates/Edinburgh University Press.

Farley, Andrew. 2004. The relative effects of processing instruction and meaning-based output instruction. In Bill VanPatten (ed.), Processing instruction: Theory, research, and commentary, 143-168. Nueva Jersey: Lawrence Erlbaum.

Fernández, Sonsoles. 1995. Errores de desarrollo y errores fosilizables en el aprendizaje de E/LE: Tratamiento didáctico. Actas del VI Congreso Internacional de ASELE: Actuales tendencias en la enseñanza del español como lengua extranjera. 147-154. 
Fernández, Sonsoles. 1997. Interlengua y análisis de errores en el aprendizaje del español como lengua extranjera. Madrid: Edelsa.

Fillmore, Charles J. 1966. Deictic categories in the semantics of 'come'. Foundations of Language 2. 219-227.

Fillmore, Charles J. 1975. Santa Cruz lectures on deixis: 1971. Bloomington: Indiana University Linguistics Club.

García Padrón, Dolores. 1985. Ir/venir - Gehen/Kommen: Dos estructuras semánticas diferentes para un mismo "designatum". Revista de Filología de la Universidad de La Laguna 4(1). 135-141.

Gathercole, Virginia. 1977. Study of the comings and goings of the speakers of four languages: Spanish, Japanese, English, and Turkish. Kansas Working Papers in Linguistics (2). 61-94.

Gathercole, Virginia. 1978. Towards a universal for deictic verbs of motion. Kansas Working Papers in Linguistics (3). 72-88

Gutiérrez-Quintana, Esther. 2005. Análisis de la interlengua de italianos aprendices de español. (ELUA) Estudios de lingüística 19. http://www.contrastiva.it/baul_contrastivo/dati/sanvi cente/contrastiva/Didáctica\%20interlengua\%20y\%20errores/Gutiérrez\%20interlengua. pdf (accessed 4 september 2013).

Hijazo-Gascón, Alberto. 2017. Motion events contrasts in Romance languages: Deixis in Spanish as a second language. In Iraide Ibarretxe-Antuñano (ed.), Motion and Space across languages: Theory and applications, 301-328 [Chapter 11] (Human Cognitive Processing). Amsterdam: John Benjamins.

Ibáñez, Jorge. 1983. Estudio de la deixis espacial en los verbos españoles ir y venir: con especial consideración del contraste en los verbos de movimiento del francés y del alemán. Hamburg: University of Hamburg dissertation.

Ibarretxe-Antuñano, Iraide \& Javier Valenzuela. 2012. Lingüística cognitiva. Barcelona: Anthropos.

Instituto Cervantes. 2006. Plan curricular del instituto cervantes: Niveles de referencia para el español. [Alcalá de Henares]. Madrid: Biblioteca Nueva.

Langacker, Ronald. 1987. Foundations of cognitive grammar 1, Theoretical prerequisites. Stanford: Stanford University Press.

Langacker, Ronald. 2008. Cognitive grammar as a basis for language instruction. In Peter Robinson \& Nick C. Ellis (eds.), The handbook of cognitive linguistics and second language acquisition, 66-88. London and New York: Routledge.

Larsen-Freeman, Diane. 2015. Research into practice: Grammar learning and teaching. Language Teaching 48(2). 263-280.

Lee, James. 2015. The milestones in twenty years of processing instruction research. International Review of Applied Linguistic in Language Teaching 53(2). 111-126.

Lenarduzzi, René. 1999. Interferencias en el aprendizaje del español en alumnos italófonos; el lexema verbal. In Norbert von Prellwitz (ed.), Lo spagnolo d'oggi: Forme della comunicazione, 243-256. Siena: Bulzoni Editore.

Lewandowski, Wojciech. 2007. Toward a comparative analysis of coming and going verbs in Spanish, German and Polish. Barcelona: University Autonoma of Barcelona MA thesis.

Lewandowski, Wojciech. 2008. Los verbos itivos y ventivos en castellano y alemán: Una propuesta de principios jerarquizados. In Antonio Moreno (ed.), El valor de la diversidad (meta) lingüística. Actas del VIII Congreso de Lingüística General, 1122-1123. Madrid: UAM. Lewandowski, Wojciech. 2014. Deictic verbs: Typology, thinking for speaking and SLA. SKY Journal of Linguistic 27. 43-65. 
Llopis-García, Reyes. 2009. Gramática Cognitiva e Instrucción de Procesamiento para la enseñanza de la selección modal: un estudio con aprendientes alemanes de español como lengua extranjera. Madrid: Universidad Nebrija dissertation.

Llopis-García, Reyes. 2016. Using cognitive principles in teaching Spanish L2 grammar. Hesperia. Anuario de filología hispánica XIX(2). 29-50.

Llopis-García, Reyes, Juan Real Espinosa \& José Ruiz Campillo. 2012. Qué gramática enseñar, qué gramática aprender. Madrid: Edinumen.

Long, Michael. 1991. Focus on form: A design feature in language teaching methodology. In Kees de Bot, Ralph Ginsberg \& Claire Kramsch (eds.), Foreign language research in cross-cultural perspective, 39-52. Amsterdam: John Benjamins.

Long, Michael \& Peter Robinson. 1998. Focus on form: Theory, research, and practice. In Catherine Doughty \& Jessica Williams (eds.), Focus on form in classroom second language acquisition, 15-63. Cambridge: Cambridge University Press.

Marongiu, Stefano. 1997. Eine kontrastive Analyseder Polysemie deiktischer Bewegungsverben. Konstanz: University of Konstanz MA thesis.

Nakazawa, Tsuneko. 2006. Motion event and deictic motion verbs as path-conflating verbs. In Stefan Müller (ed.), Proceedings of the 13th International Conference on Head-Driven Phrase Structure Grammar, Varna 284-304. Stanford, CA: CSLI Publications.

Nakazawa, Tsuneko. 2007. A typology of the ground of deictic motion verbs as path-conflating verbs: The speaker, the addressee, and beyond. Poznań Studies in Contemporary Linguistics 43(2). 59-82.

Nakazawa, Tsuneko. 2009. A typology of the path of deictic motion verbs as path-conflating verbs: The entailment of arrival and the deictic center. Poznań Studies in Contemporary Linguistics 45(3). 385-403.

Oshima, David. 2006. GO and COME revisited: What serves as a reference point? Annual Meeting of the Berkeley Linguistics Society 32(1). 287-298.

Palacio, Blanca. 2013. Un estudio sobre la enseñanza de la oposición Imperfecto-Indefinido a estudiantes malteses de ELE. Revista Nebrija de Lingüística Aplicada a la Enseñanza de Lenguas 13. https://www.nebrija.com/revista-linguistica/un-estudio-sobre-laenseñanza-de-la-oposicion-imperfecto-indefinido-a-estudiantes-malteses-de-ele.html (accessed 14 June 2015).

Rakaseder, Johanna \& Astrid Schmidhofer. 2014. Errores de producción de textos por parte de germanoparlantes en las primeras etapas de aprendizaje de ELE. Revista Didáctica Español Como Lengua Extranjera 19. http://marcoele.com/descargas/19/rakaseder_schmidhofererrores-alemanes.pdf (accessed 15 Februar 2015).

Ricca, Davide. 1991. Andare e venire nelle lingue romanze e germaniche: Dall'Aktionsart alla deissi. Archivio Glottologico Italiano 76(2). 159-192.

Ricca, Davide. 1993. I verbi deittici di movimento in Europa: Una ricerca interlinguistica. Pavia: La Nuova Italia edn.

Sánchez-Iglesias, Jorge. 2003 Errores, corrección y fosilización en la didáctica de lenguas afines: Análisis de errores en la expresión escrita de estudiantes italianos de E/LE. Portal de gramática y de lingüística contrastiva español italiano. http://www.contrastiva.it/baul_con trastivo/dati/sanvicente/contrastiva/Didáctica\%20interlengua\%20y\%20errores/Sánchez\% 20Iglesias\%20Corrección\%20de\%20errores.pdf (accessed 13 July 2013).

Slobin, Dan. 1996. From thought and language to thinking for speaking. In John Gumpertz \& Stephen C. Levinson (eds.), Rethinking linguistic relativity, 70-96. Cambridge: CUP. 
Suadoni, Anna. 2016. Verbos de movimiento, deixis y proyección metafórica. El caso de andare y venire en contraste con ir y venir. Granada: University of Granada dissertation.

Sudo, Yasutada. 2015. Come and go. Talk at the Perspectives in Context Workshop, GeorgAugust Universität Göttingen, 10 July.

Tapia Yepes, Eduard. 2011. Gebrauch von gehen und kommen im Kontext: diathetische und deiktische Alternanz nach textthematischer, multimodaler und stilistischer Variation. Barcelona: University of Barcelona dissertation.

VanPatten, Bill. 1996. Input processing and grammar instruction: Theory and research. Nueva Jersey: Ablex Publishing Corporation.

VanPatten, Bill. 2002. Processing instruction: An update. Language Learning 52(4). 755-803.

VanPatten, Bill. 2004. Input processing in second language acquisition. In Bill VanPatten (ed.), Processing instruction: Theory, research, and commentary, 5-31. Mahwah, NJ: Lawrence Erlbaum and Associates.

VanPatten, Bill \& Teresa Cadierno. 1993. Explicit instruction and input processing. Studies in Second Language Acquisition 15(2). 225-243.

Vázquez, Graciela. 1991. Análisis de errores y aprendizaje de español lengua extranjera. Frankfurt am Main: Peter Lang.

Verde, Erica, 2014. Investigating Miami English-Spanish Bilinguals' Treatment of English Deictic Verbs of Motion (2014). Miami: Florida International University MA thesis. 